\title{
President's Message: 21st Century Skills, 21st Century Infrastructure
}

$\mathrm{T}$ wenty years ago, librarians became involved in the implementation of the Internet for the use of the public across the country. Those initiatives were soon followed by the Bill and Melinda Gates Foundation projects supporting public libraries, which included funding hardware grants to implement public computer labs and connectivity grants to support high-speed Internet connections. In 2008, the Institute of Museum and Library Services (IMLS) convened a task force to define twentyfirst-century skills for museums and libraries, which became an ongoing national initiative (http://www.imls .gov/about/21stCSkills.shtm). The one year anniversary of the release of the National Broadband Plan was March 16, 2011. As described on Broadband.gov, the plan is intended "to create a high-performance America-a more productive, creative, efficient America in which affordable broadband is available everywhere and everyone has the means and skills to use valuable broadband applications." 1

In 1994, the Idaho State Library's Development Division cosponsored eight focus groups in which 179 people participated. The participants were asked several questions, including the types of information they would like to see on the Internet. The results reflected the public's interest at that time in the following:

- "expert advice on a variety of topics including medicine, law, car repair, computer technology, animal husbandry, and gardening

- economic development, investment, bank rates, consumer product safety, and insurance

- community-based information such as events, volunteers, local classified advertisements, special interest groups, housing information, public meetings, transportation schedules, and local employment opportunities

- computer training, foreign language programs, homework service, teacher recertification, school activities, school scheduling, and adult education

- electronic mail and the ability to transfer files locally as well as worldwide

- access to public records, voting records of legislators, absentee voting, the ability to renew a driver's license, the rules and regulations from governmental agencies, and taxes

- information about hunting and fishing, environmental quality, the local weather, road advisories, sports,

Karen J. Starr (karen.j.starr@gmail.com) is LITA President 2010-11 and Assistant Administrator for Library and Development Services, Nevada State Library and Archives, Carson City. recreation, law enforcement and public safety, and social services available in the community

- access to electronic encyclopedias, local libraries' catalogs, full-text articles online, and document delivery." ${ }^{2}$

At the time we were asking the question, will an information infrastructure be built? The answer? Most assuredly. Indeed, librarians stepped up to the table and ensured that the public had access to information-related services at their local library. The information the public asked for in 1994, as listed above, is widely available today. There are numerous examples in which librarians and libraries have served as leaders in the ongoing sustainablity of local, regional, and national information networks. It was pointed out at the time, and remains true today, that in an era of ever-shrinking resources, libraries cannot and should not compete with telecommunications, entertainment, and computer companies. They need to "join them as equals in the information arena." ${ }^{3}$

LITA has a viable role in the development of the twentyfirst-century skills that will firmly put the information infrastructure into place. A LITA member is appointed as a liaison to the Office for Information Technology Policy (OITP) and serves on the LITA Technology and Access Committee, which addresses similar issues. The LITA Transliteracy Interest Group explores, develops, and promotes the role of libraries in all aspects of literacy. Working with the OITP provides LITA membership with the opportunity to participate in current issues, such as digital literacy.

The information infrastructure has come a long way in the last twenty some years. There is still much to be done. Robert Bocher, Technology Consultant with the Wisconsin State Library and OITP Fellow, will present "Building the Future: Addressing Library Broadband Connectivity Issues in the 21st Century" at the LITA President's Program from 4 p.m. to 5:30 p.m. on Sunday, June 26, at the ALA Annual Conference in New Orleans. I look forward to seeing you at the program and to hear about the successes and the work that remains to be done to address the broadband needs we all face in the country.

\section{References}

1. Federal Communications Commission, The National Broadband Plan: Chapter 2: Goals for a High Performance America, http://www.broadband.gov/plan/2 -goals-for-a-high-performance-america/ (accessed Apr. 2, 2011).

2. Karen Starr, "The American Public, the Public Library, and the Internet; an Ever-Evolving Partnership" in The Cybrarian's Manual, ed. Pat Ensor (Chicago: ALA, 1997): 23-24.

3. Ibid., 31 . 